\title{
The effects of river normalization on flood risk
}

\author{
Nurhamidah Nurhamidah ${ }^{1}$, Ahmad Junaidi ${ }^{1}$, Haviz Ramadhan ${ }^{1 *}$, and Ronny Eka Putra ${ }^{1}$ \\ ${ }^{1}$ Department of Civil Engineering, Faculty of Engineering, University of Andalas, Padang.
}

\begin{abstract}
A river is a naturally occurring flow system that flows from upstream to downstream. Rivers have many benefits. Similarly, rivers have a negative impact if rainfall is high. It can lead to catastrophic flooding. Flooding often occurs along the central roads of Padang City when it rains, especially in the Maransi and Aie Pacah areas. The purpose of this study is to estimate the height of water level by using software HEC - RAS and estimate areas that have the potential for flooding in conditions before and after river normalization by using the software Arc-GIS. Data collection is carried out to achieve this goal, namely the maximum daily rainfall data, Digital Elevation Model (DEM) data obtained from the processing of aerial photo data, and cross-sectional data of the river. Then, a numerical simulation is performed to estimate the height of the water level, and then a numerical simulation is performed to determine the extent of the flood area. The results of this study are in the form of flood areas in conditions before and after river normalization with a period of 25,50 , and 100 years that can be used to see the effectiveness of river normalization work in the river.
\end{abstract}

\section{Introduction}

Batang Maransi River is a river located in West Sumatera Province [1], Padang City, Koto Tangah District. The land area of Padang City is $\pm 694.96 \mathrm{~km}^{2}$ and has \pm 23 streams with a total length of $155.40 \mathrm{~km}$ (10 major rivers and 13 small rivers). Generally, the large and small rivers in the Padang city area are not much different from the sea level height.

Batang Maransi River is one of the rivers that are prone to flooding in the rainy season. Batang Maransi River crosssection is not able to accommodate the high rainfall of Padang City, so during the rainy season in the area around Maransi and Aie Pacah, there are often floods. One of the largest floods ever occurred in the area around Batang Maransi, Koto Tangah district on March 22, 2016, where nine subdistricts in Padang City were flooded with a rain intensity of $384 \mathrm{~mm}$. Especially in West Padang District, precisely at Maransi, floods entering residents' housing with a puddle height of $50-100 \mathrm{~cm}$ make residents required to leave their homes.

Therefore, it is necessary to reconstruct the river in Batang Maransi. The normalization of the river in an attempt to increase the capacity of the river. River normalization consists of channel improvement such as building new channels, widening or deepening the channel, channel resectioning, channel realignment, bank protection, build dikes and dams(retarding and storage dam) [2]. Currently, the Batang Maransi River is ongoing normalization of the river to overcome the flood problem in the Maransi and Aie Pacah areas, Koto Tangah Subdistrict which is one of the flood vulnerable areas. Floods can be inferred as a relatively high flow that transcends natural or artificial embankments in the river, varying magnitude by season, month to month, year to year [3]. The flooding problems damages might be the result of area cultivation and land-use changes without any control. In addition, it seems that increasing rainfall intensities in the upstream catchments of the river and a city are contributing to the problem of flooding as well. [4] Therefore, flooding in this area has become the center of attention of the government.

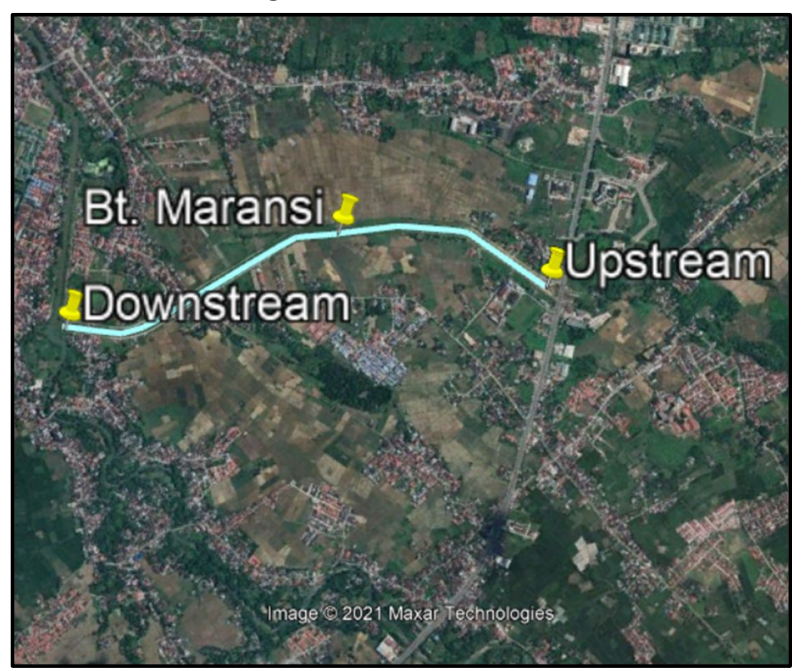

Fig. 1. Long section in Batang Maransi River.

The main objective of this study is to see the effectiveness of river normalization to reduce the risk of flooding. The specific purpose of this study is to estimate the height of the river face, then map and estimate the area of inundation of areas that have the potential flood in conditions before and after normalization in Batang Maransi River. The benefit of this study is as a reference

\footnotetext{
*Corresponding author: havizramadhan27@gmail.com
} 
to manage flood problems as a reference in the policymaking of flood management in the area around Batang Maransi River.

\section{Literature Review}

The research entitled Flood Analysis Using HEC-RAS Software with a case study of sub-watershed Cisemeut downstream HM $0+000$ to HM $69+00$ which aims to determine the cause of the existing flooding in the region based on the capacity with discharges that occur and know the ability of the Cisimeut downstream watershed segment in accommodating river flow discharge with 50year period. From the analysis results, hydrological analysis to get the discharge of flood plans 50-year period of $1566,439 \mathrm{~m}^{3} / \mathrm{s}$ and then conducted a hydraulic analysis using HEC-RAS application with a steady flow and unsteady flow conditions. The result is that the capacity of the Cisimeut river in existing conditions is not able to flow the flood discharge plan, so flood control efforts are needed. Although water discharge is reduced, there is still an overflow of the river at some point. Therefore, it is necessary to repair the cross-section of the river and the elevation of the embankment to increase the capacity of the river so that the overflow can be resolved [5]

The research with the title Cilemer Watershed Flood Analysis HM 0+000 - HM 53+000 aims to identify floodaffected areas in Pandeglang Regency at HM 00+00 to HM 53+00, which can then produce recommendations in flood management. The research supporting data was obtained from the Water Resources Management Center of Banten Province. The analysis calculated the planned flood discharge based on the maximum debit data for a moment by the Mean Annual Flood (MAF) method and obtained the planned flood discharge data of 210,617 $\mathrm{m}^{3} / \mathrm{s}$. Then, flood modeling and mapping were carried out by simulating the flow using the HEC-RAS application and conducted flood modeling carried out modeling of flood-affected areas by using the Arc-GIS application. The conclusions obtained from the results of the study were river flow simulation and flood mapping using HECRAS and Arc-GIS applications. It was seen that 19 crosssection segments of the river (HM $35+00$ to HM 53+00) of Cilemer watersheds reviewed could not accommodate the planned flood discharge [6]

The study, titled Flood Mapping Study with HECGeoRAS with case studies on the Tondano River to create a 2014 flood inundation map in Manado geographic information system (GIS) overlay on google earth. From the analysis, the maximum debit data was obtained on January 15, 2014, and obtained maximum debit data of $1300 \mathrm{~m}^{3} / \mathrm{s}$. Then, a hydraulics simulation was carried out using the HEC-GeoRAS application which appears in the form of tools in the Arc-GIS application by inputting maximum flood discharge data and carrying out flood modeling simulation with the result that the flood height is estimated at 0 meters to 6 meters, including the height of flooding in the river and the results of simulations with HEC-GeoRAS obtained flood speed is estimated at $0 \mathrm{~m} / \mathrm{s}$ up to $42.9 \mathrm{~m} / \mathrm{s}$. [7]

\section{Research Methodology}

Research methodology is done by identifying problems according to the available data. Data collection is divided into two, namely primary and secondary. The primary data needed is cross-sectional measurement data across the river measured and by using water pass, channel roughness figure data that is reviewed based on material from the cross-section of the channel reviewed and aerial photo data of Batang Maransi River and surrounding areas taken using drones. While the secondary data needed are annual rainfall data, weir dimension data and floodgates, cross-sectional data of rivers obtained from Water Resources Management Office, West Sumatera, and Digital Elevation Model (DEM) data that can be obtained from the Geospatial Information Agency website. The methodology is carried out by conducting a hydrological analysis to obtain the value of the flood discharge plan. Then, hydraulic analysis is done, estimating the water level using software HEC-RAS. After obtaining a high water level value, in a numerical simulation to estimate the area of flood area using the software Arc-GIS. This Modeling data uses an approach with the D8 matrix to determine where the flow direction and flow accumulation are. [8]. The data is collected from various sources and it may overlap information from various data sources through various themes and layers [9]. Arc-GIS can also be used for scientific investigation, cartography, road planning and can also assist in planning in calculating responses quickly. [10]

\subsection{Description of The Study Area}

Batang Maransi is one of the rivers located in the city of Padang, West Sumatra, that has a role in draining the amount of water discharge flowing, starting from upstream located in Batang Lurus River and Batang Belimbing River, which is downstream of Batang Maransi. By reconstructing the river, namely dredging the Batang Maransi River and the construction of weir, the risk of flooding in the area can be minimized.

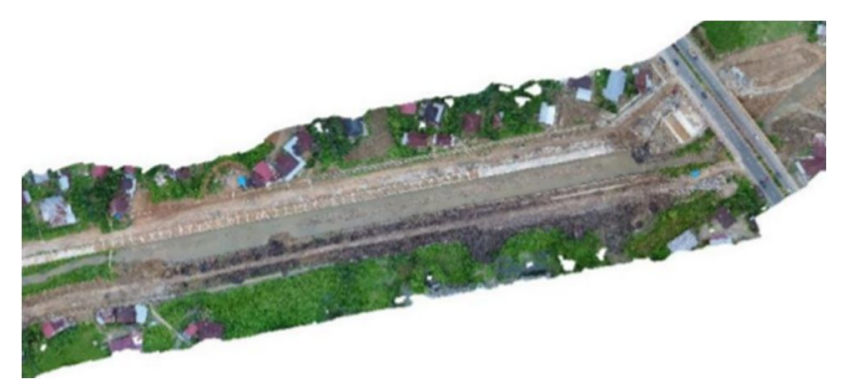

Fig. 2. Condition of Batang Maransi River.

\section{Result and Discussion}

\subsection{Hydrology Analysis}

Hydrological analysis in this study requires rainfall data for 20 years obtained Water Resources Management Office, West Sumatera. The rainfall station in need is 
Gunung Sarik Rain Station. The daily rainfall data is recapitulated into maximum rainfall every month and carried out the calculation of the rainfall plan. Then, the calculation of concentration-time and intensity of rain with a period of 25,50 , and 100 years. So, the value of flood discharge plan with the rational method in the period of 25, 50, and 100 years can be seen in Table 1 .

$$
Q=0,278 \times C \times I \times A
$$

Description:

$$
\begin{aligned}
\mathrm{Q} & =\text { Debit Max }(\mathrm{m} 3 / \mathrm{s}) \\
\mathrm{C} & =\text { Flow Coefficient } \\
\mathrm{I} & =\text { Rain Intensity }(\mathrm{mm} / \text { hours }) \\
\mathrm{A} & =\text { Catchment Area }\left(\mathrm{Km}^{2}\right)
\end{aligned}
$$

Table 1. Rational Discharge Plan Method.

\begin{tabular}{|c|c|c|c|c|}
\hline \multirow{2}{*}{ Year } & \multirow{2}{*}{$\mathbf{C}$} & $\mathbf{A}$ & $\mathbf{I}$ & $\mathbf{Q}_{\mathbf{t}}$ \\
\cline { 3 - 5 } & & $\mathbf{K m}^{\mathbf{2}}$ & $\mathbf{m m} / \mathbf{j a m}$ & $\mathbf{m}^{\mathbf{3}} \mathbf{s}$ \\
\hline 10 & 0,175 & 17,18 & 70,038 & 58,637 \\
\hline 25 & 0,175 & 17,18 & 87,862 & 73,559 \\
\hline 50 & 0,175 & 17,18 & 102,198 & 85,562 \\
\hline 100 & 0,175 & 17,18 & 117,387 & 98,277 \\
\hline
\end{tabular}

In this study, assuming the discharge that goes into the side drain amounting to $20 \%$ of the flood discharge plan, so that the calculation of flood discharge plan period of 25 years, 50 years and 100 years after there is a discharge that goes into the side drain can be seen in Table 2.

Table 2. Discharge plan after side drain.

\begin{tabular}{|c|c|c|}
\hline \multirow{2}{*}{ Year } & $\mathbf{Q}_{\mathbf{t}}$ & $\mathbf{Q}$ \\
\cline { 2 - 3 } & $\mathbf{m}^{\mathbf{3}} / \mathbf{s}$ & $\mathbf{m}^{\mathbf{3}} / \mathbf{s}$ \\
\hline 10 & 58,637 & 70,364 \\
\hline 25 & 73,559 & 88,271 \\
\hline 50 & 85,562 & 102,674 \\
\hline 100 & 98,277 & 117,933 \\
\hline
\end{tabular}

\subsection{Hydraulic Analysis}

The hydraulic analysis is performed by estimating the water level with software HEC-RAS with steady flow conditions. The results of the simulation of steady flow conditions before river normalization conditions showed that there were more flood points than after river normalization conditions.

The picture above shows the simulation results of HEC-RAS in conditions before river normalization, Q10 there are 39 points of runoff, that is Sta $0+200$ to Sta $1+150$, in Q25 there are 39 points of runoff, that is from Sta $0+200$ to Sta. Sta $1+150$, in Q50 there are 39 points of runoff, that is from Sta $0+200$ to Sta $1+150$, in Q100 there are 41 points of runoff, that is from Sta $0+150$ to Sta $1+150$.
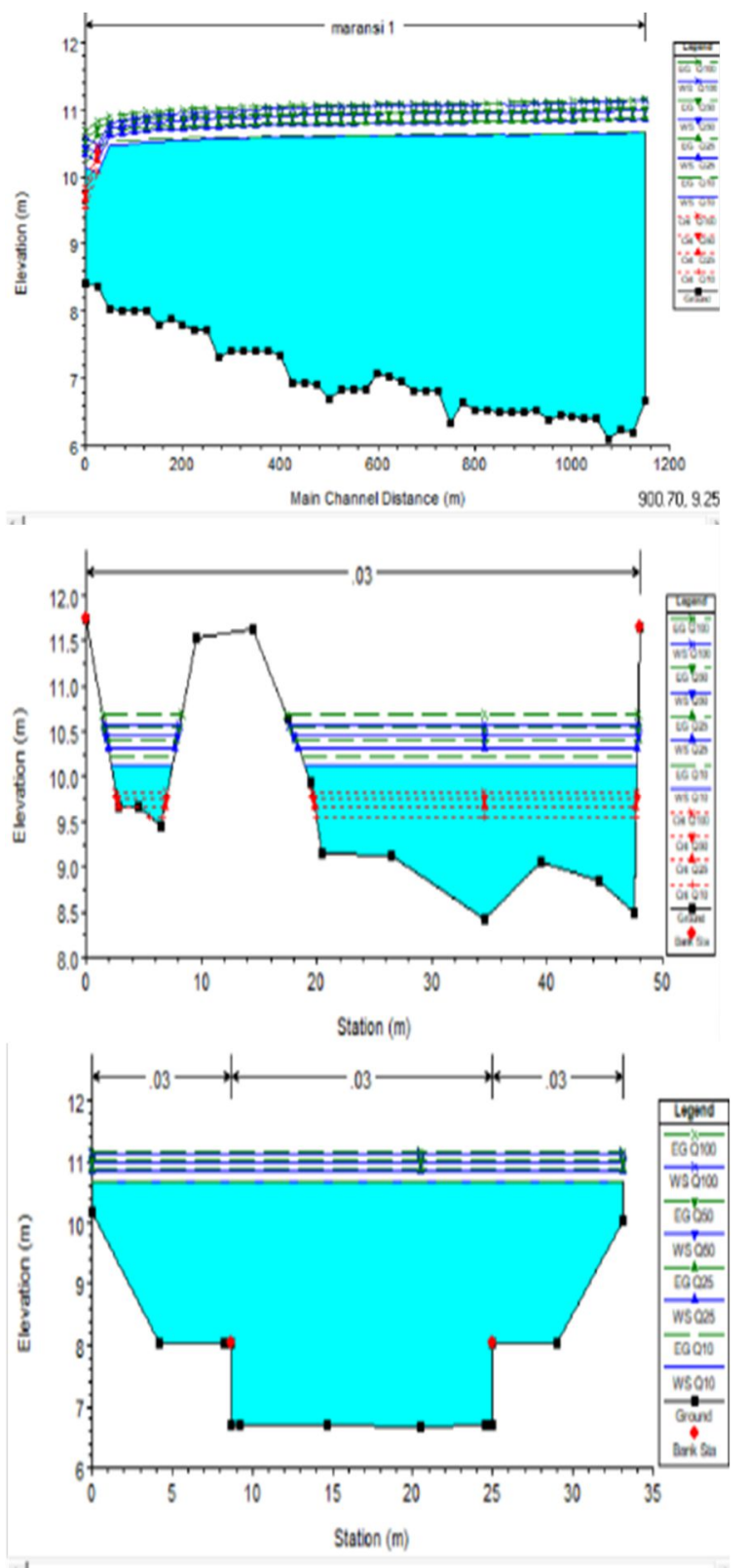

Fig. 2. Water level profile in before river normalization conditions in Batang Maransi River.

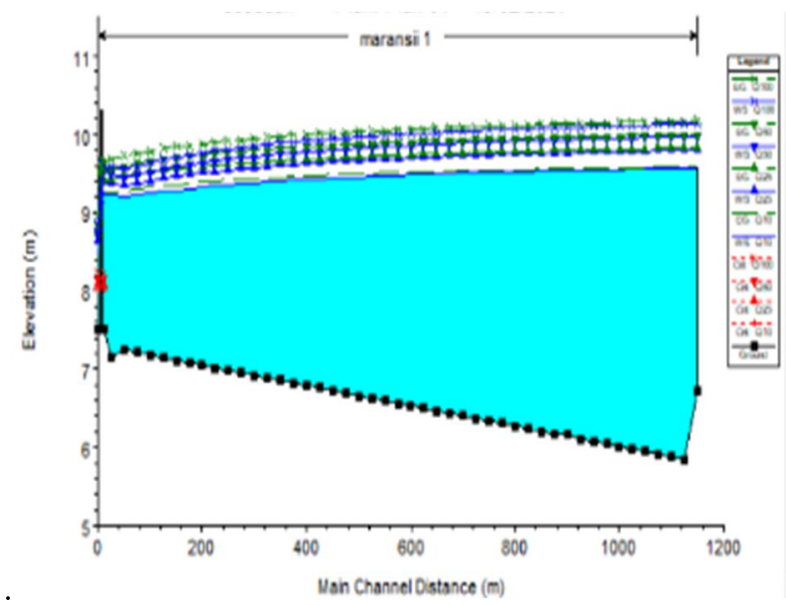



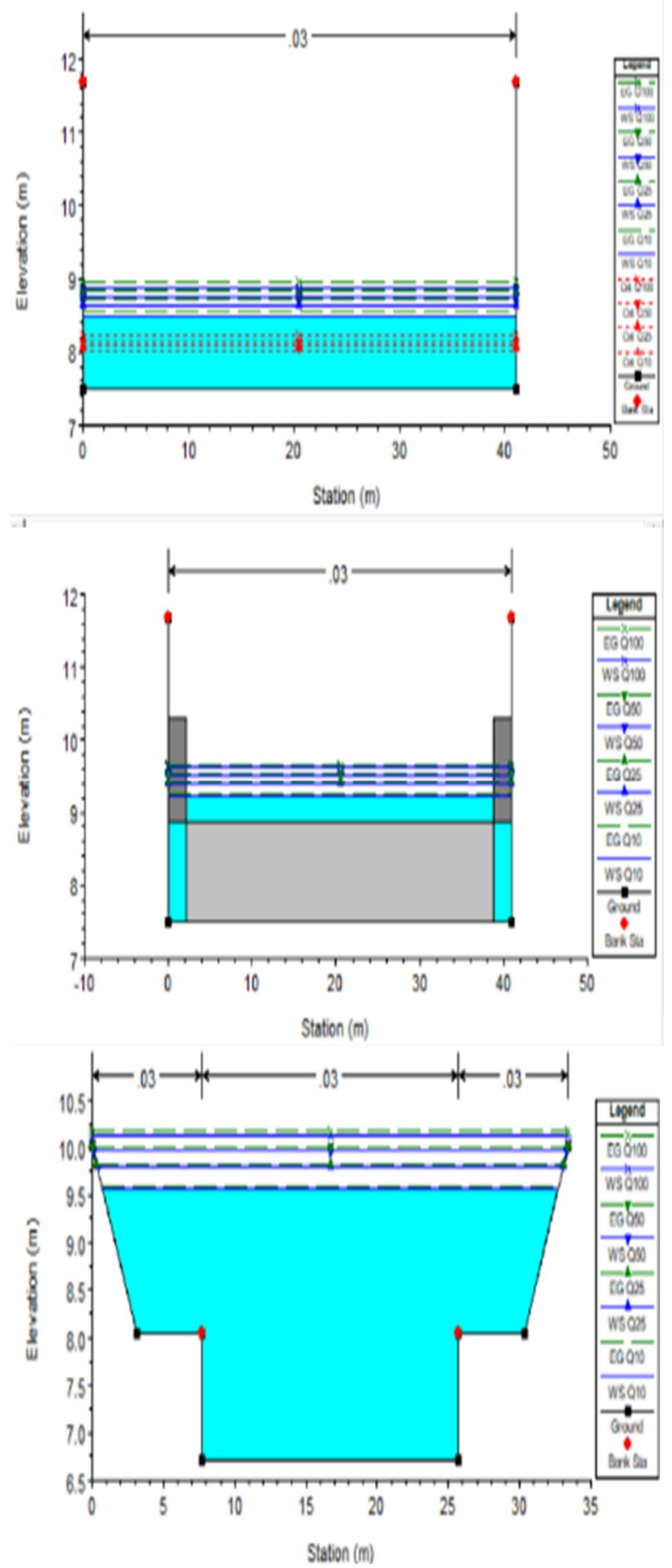

Fig. 3. Water level profile in after river normalization conditions in Batang Maransi River.

In the picture above, it is obtained that the simulation result of HEC-RAS in after river normalization conditions, the points of runoff is only found in Q100, namely at Sta $1+100$ to Sta $1+150$. There is a graph describing the comparison of water level elevation in conditions before and after river normalization in Fig 4.

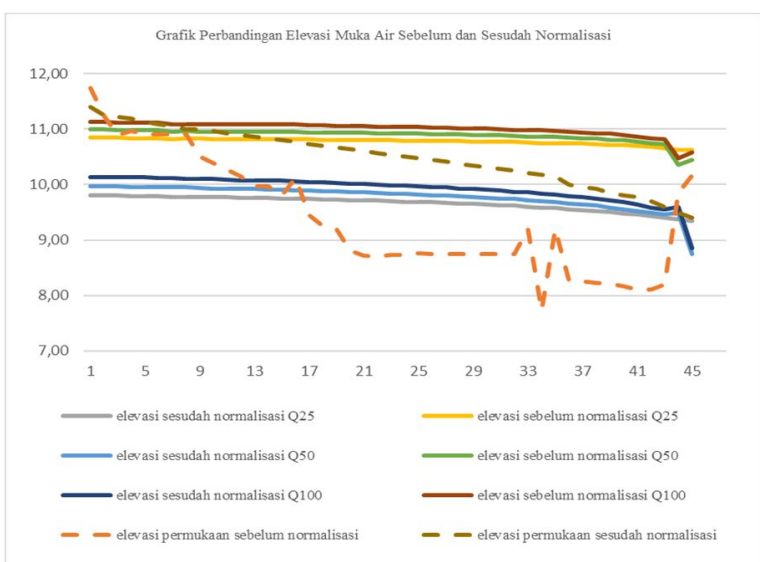

Fig. 4. Water level elevation comparison graph before and after river normalization in Batang Maransi River.

\subsection{Flood Modeling Area}

Based on the results of hydraulic analysis data obtained, namely the water level in Batang Maransi River, can be displayed modeling from the simulation of flood Batang Maransi River by using software Arc-GIS 10.4 version that can be seen in conditions before and after river normalization.

\subsubsection{Before normalization}

From the results of the flood, simulation obtained the area of flood area is $129.40 \mathrm{Ha}$ for a 25 -year return period, 138.38 Ha for a 50-year return period, 147.61 Ha for a 100 -year return period. Simulation modeling results can be seen in Fig 4 for a 25-year return period, Fig 5 for a 50year return period, Fig 6 for a 100-year return period.

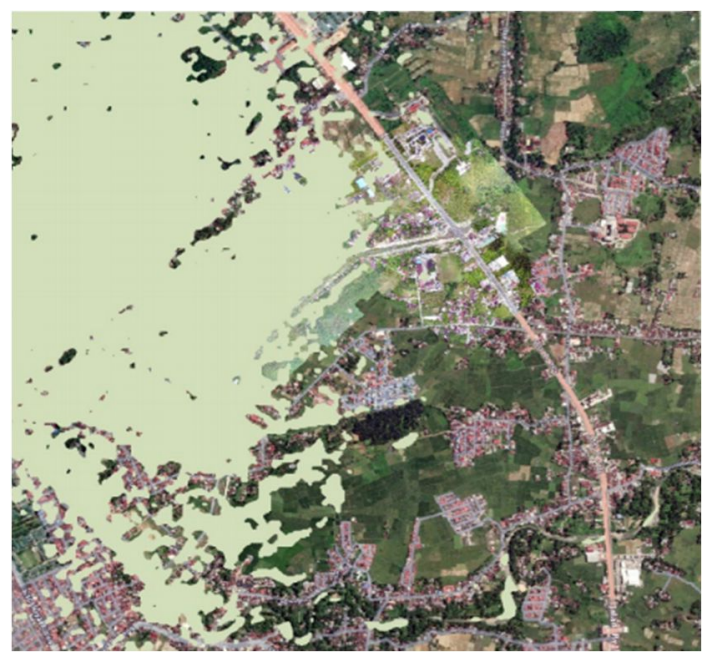

Fig. 5. Flood modeling results of conditions before river normalization with 25 years period in Batang Maransi River. 


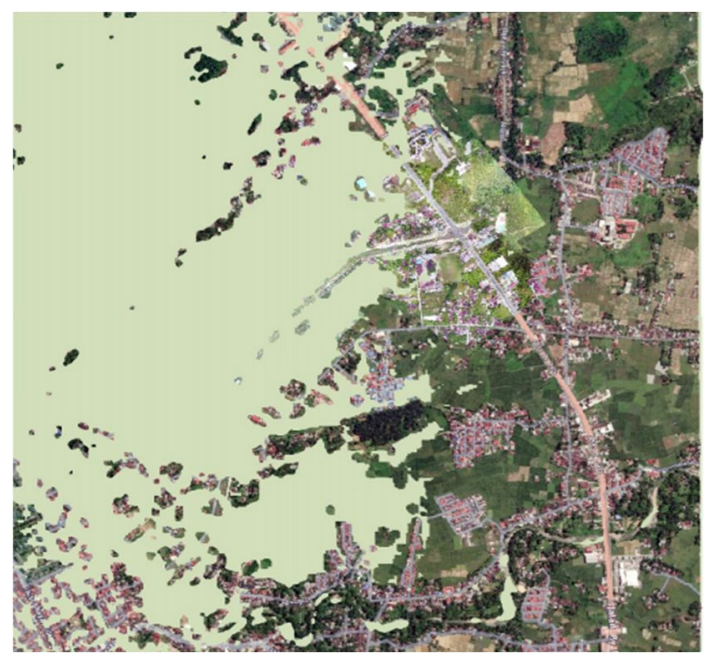

Fig. 6. Flood modeling results of conditions before river normalization with 50 years period in Batang Maransi River.

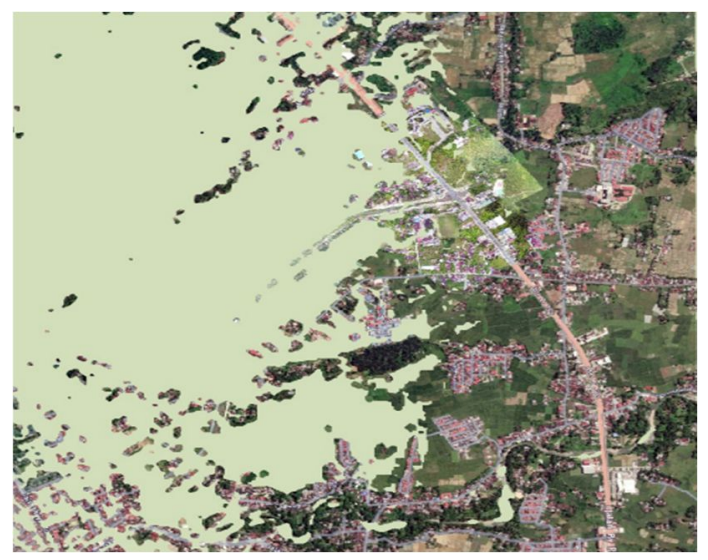

Fig. 7. Flood modeling results of conditions before river normalization with 100 years period in Batang Maransi River.

\subsubsection{After river normalization}

From the results of a flood, simulation obtained the area of flood area is $64.51 \mathrm{Ha}$ for a 25-year return period, 71.73 Ha for a 50 -year return period, 79.38 Ha for a 100 -year return period. Simulation modeling results can be seen in Fig 7 for 25 -year, Fig 8 for a 50-year return period, Fig 9 for a 100 -year return period.

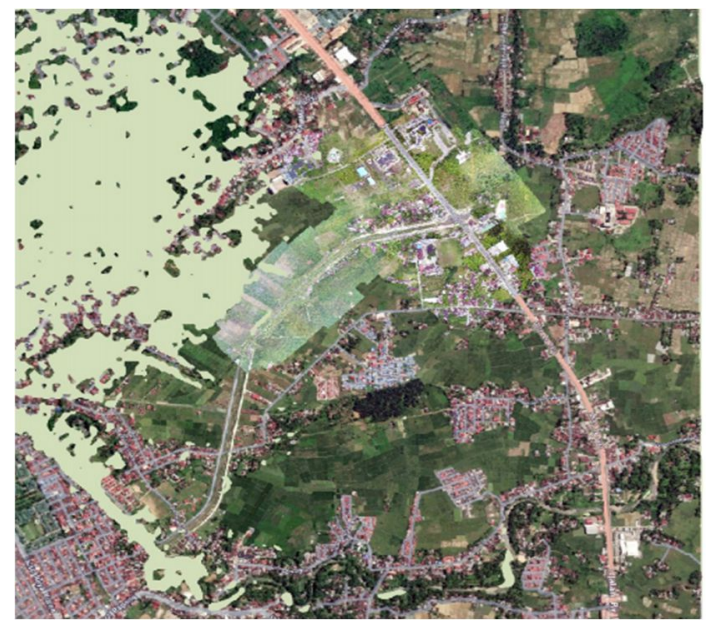

Fig. 8. Flood modeling results of conditions after river normalization with 25 years period in Batang Maransi River.

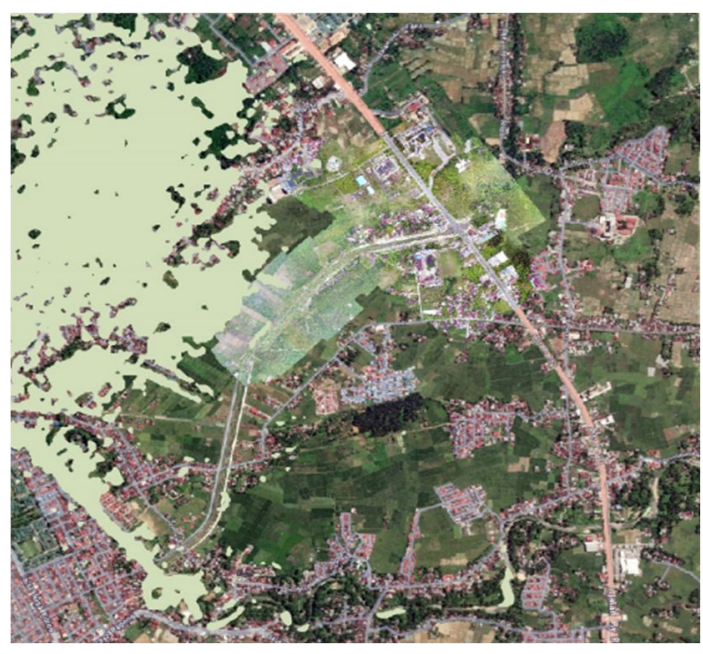

Fig. 9. Flood modeling results of conditions after river normalization with 50 years period in Batang Maransi River.

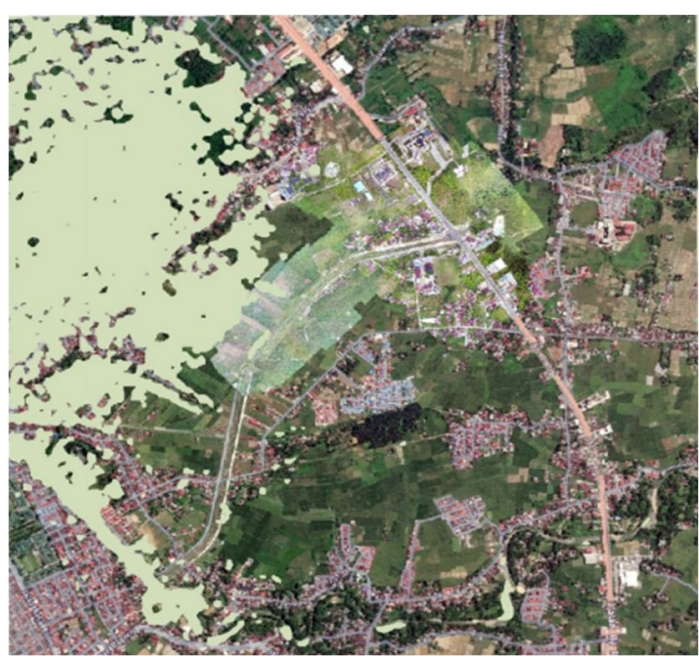

Fig. 10. Flood modelling results of conditions after river normalization with a 100 years period in Batang Maransi in Batang Maransi in Batang Maransi River.

Technically, Batang Maransi River flood control is expected to be able to manage peak discharge, their riverbeds can be used as a water reservoir, and the river environment is functional.[11]

\section{Conclusion}

From the research that has been done, can be concluded as follows:

1. In hydrology analysis, the debit value of the plan is used rational method. The results obtained by rational method are $\mathrm{Q} 10=58,637 \mathrm{~m}^{3} / \mathrm{s}, \mathrm{Q} 25=73,559 \mathrm{~m}^{3} / \mathrm{s}$, $\mathrm{Q} 50=85,562 \mathrm{~m}^{3} / \mathrm{s}, \mathrm{Q} 100=98,277 \mathrm{~m}^{3} / \mathrm{s}$ and assumed discharge that goes to the side drain of $20 \%$ of the river discharge, so that the discharge flood plan after taking into account the discharge that goes into the side drain is $\mathrm{Q} 10=46,909 \mathrm{~m}^{3} / \mathrm{s}, \mathrm{Q} 25=58,847 \mathrm{~m}^{3} / \mathrm{s}, \mathrm{Q} 50=$ $68,849 \mathrm{~m}^{3} / \mathrm{s}, \mathrm{Q} 100=78,622 \mathrm{~m}^{3} / \mathrm{s}$.

2. In hydraulic analysis, the simulation results using software HEC-RAS in steady flow conditions showed the flood point that occurred in the before river 
normalization condition more than after river normalization condition.

3. Before river normalization, in Q10 there were 39 flood points, namely from Sta $0+200$ to Sta $1+150$, in Q25 there are 39 flood points, namely from Sta $0+200$ to Sta $1+150$, in Q50 there are 39 flood points that are from Sta $0+200$ to Sta $1+150$, in Q100 there are 41 flood points that are from Sta $0+150$ to Sta $1+150$. In the condition after river normalization, the point of flooding only occurs in Q100, 3 flood points are at Sta $1+100$ to Sta $1+150$.

4. From several periods using the software Arc-GIS version, the area of flooding before river normalization is greater than after the river normalization of Batang Maransi River because it has been done river normalization.

5. The results were done by simulation using software Arc-GIS version along $1,150 \mathrm{~km}$, obtained calculation of flood area that is before river normalization Q10 = 118.41 Ha, Q25 = 129.40 Ha, Q50 = 138.38 Ha, Q100 $=147.61 \mathrm{Ha}$ and after river normalization $\mathrm{Q} 10=54.71$ Ha, Q25 = 64.51 Ha, Q50 = 71.73 Ha, Q100 = 79.38 Ha.

6. DEM data from Geospatial Information Agency can only be used for steep areas, whereas for relatively flat areas should be helped with DEM data from areal photos of drones.

7. From this research can be concluded that the river normalization on the Batang Maransi River proved to be effective.

This research/article's publication in supported by Department of Civil Engineering, Faculty of Engineering, Andalas University through Funding Research fiscal year 2021 with assignment agreement letter No 127/UN16.09.D/PL/2021.

\section{References}

1. Water Resources Development Profile, The government of West Sumatra Province, PSDA Sumatera Barat,(2018).
2. Winsemius, H. C., Aerts, J. C., Van Beek, L. P., Bierkens, M. F., Bouwman, A., Jongman, B., ... \& Ward, P. J. Global drivers of future river flood risk. Nature Climate Change, 6(4), 381-385. (2016).

3. Cummings, D., et al., The tide-dominated Han River Delta, Korea: Geomorphology, sedimentology, and stratigraphic architecture, Elsevier (2015).

4. ChowVenTe, Maidment, Mays Larry W., Applied Hydrology, McGraw, Hill International Edition (1988).

5. R. Wigati, Sudarsono, I.D Cahyani, Analisis Banjir Menggunakan Software HEC-RAS 4.1(Studi Kasus sub DAS Cisimeut hilir HM 0+000 Sampai dengan HM 69+00), Jurnal Fondasi, 5 (2016).

6. R. Wigati, F.A. Arifin, M.D.Lestari, Analisis Banjir Analisis Banjir Sub DAS Cilemer HM 0+00 - HM 53+00, Jurnal Ilmiah Rekayasa Sipil, 17(2020).

7. D. Makaesaehe, L.A.Hendratta, J.S.F. Sumarauw, Kajian Pemetaan Banjir Dengan HEC-GEORAS Studi Kasus: Sungai Tondanao, Jurnal Sipil Statik, 8 (2020).

8. Nurhamidah, N., A. Junaidi, and L. Anggraini, An Immediate Review of Flood Characteristics on Delta Lowland Sumatra using D8 Model Spatial Analysis, International Journal of Earth Sciences and Engineering, 9 (2016).

9. Saha, A. K., \& Agrawal, S. Mapping and assessment of flood risk in Prayagraj district, India: a GIS and remote sensing study. Nanotechnology for Environmental Engineering, 5. (2020).

10. Ntajal, J., Lamptey, B. L., Mahamadou, I. B., \& Nyarko, B. K. Flood disaster risk mapping in the lower Mono river basin in Togo, West Africa. International journal of disaster risk reduction, 23. (2017).

11. Fang, J., Kong, F., Fang, J., \& Zhao, L. Observed changes in hydrological extremes and flood disaster in Yangtze River Basin: spatial-temporal variability and climate change impacts. Natural Hazards, 93(1), 89-107. (2018) 